\title{
Chromium supplementation and substitution of barley grain with corn: Effects on performance and lactation in periparturient dairy cows
}

\author{
H. Sadri, ${ }^{\dagger}{ }^{1}$ G. R. Ghorbani, ${ }^{*}$ H. R. Rahmani, ${ }^{*}$ A. H. Samie, ${ }^{*}$ M. Khorvash, ${ }^{*}$ and R. M. Bruckmaier† \\ *Department of Animal Science, Isfahan University of Technology, Isfahan 84156, Iran \\ †Veterinary Physiology, Vetsuisse Faculty, University of Bern, Bremgartenstr. 109a, CH-3001 Bern, Switzerland
}

\begin{abstract}
Thirty-two multiparous Holstein cows were used to investigate the effects of chromium-L-methionine (CrMet) supplementation and dietary grain source on performance and lactation during the periparturient period. Cows were fed a total mixed ration consisting of either a barley-based diet (BBD) or a corn-based diet (CBD) from $21 \mathrm{~d}$ before anticipated calving through $28 \mathrm{~d}$ after calving. The Cr-Met was supplemented at dosages of 0 or $0.08 \mathrm{mg}$ of $\mathrm{Cr} / \mathrm{kg}$ of metabolic body weight. The study was designed as a randomized complete block design with 2 (Cr-Met levels) $\times 2$ (grain sources) factorial arrangement. There was no Cr effect on prepartum dry matter intake (DMI) or postpartum DMI, body weight (BW), net energy balance, and whole tract apparent digestibility of nutrients. Prepartum DMI as a percentage of BW tended to increase with Cr-Met. Supplemental Cr-Met tended to increase milk yield whereas milk protein percentage decreased. Pre- and postpartum DMI, BW, net energy balance, milk yield, and milk composition were not affected by substituting ground barley with ground corn. The addition of Cr-Met increased prepartum DMI and tended to increase postpartum DMI of the BBD but not the CBD. The change in prepartum DMI was smaller when the BBD was supplemented with Cr-Met but remained unchanged when the CBD was supplemented with $\mathrm{Cr}$ Met. Yields of crude protein and total solids in milk and prepartum digestibility of DM and organic matter tended to increase when Cr-Met was added to the BBD but remained unchanged when added to the CBD. Periparturient cows failed to respond to the grain source of the diet, whereas they showed greater response in milk yield to diets supplemented with Cr-Met. In conclusion, the present results demonstrate that the beneficial effect of Cr-Met supplementation during the periparturient period to improve feed intake may depend on the grain source of the diet.
\end{abstract}

\footnotetext{
Received November 7, 2008.

Accepted July 11, 2009.

${ }^{1}$ Corresponding author: sadrih@ag.iut.ac.ir
}

Key words: chromium, barley and corn grain, periparturient cow

\section{INTRODUCTION}

The transition period, 3 wk before until 3 wk after calving, is crucial for cow health and production (Grummer, 1995). The nutritional demands of the fetus increase considerably during late gestation whereas feed consumption declines during the last 3 wk of gestation (Hayirli et al., 2002), resulting in decreased nutrient intake. Reduced feed intake may potentiate negative nutrient balance and make dairy cows less efficient at adapting to the physiological changes of gestation. Moreover, Grummer et al. (2004) proposed that the most important signal for initiating adipose tissue lipolysis may be the magnitude of intake depression rather than the level of DMI during the prepartum period.

Various additives are used in transition dairy cow rations to minimize metabolic problems. Among these, Cr supplementation has been used during pregnancy, lactation, and other times of stress. Chromium is biologically active as part of a biomolecule called chromodulin, which is part of an insulin-signaling pathway, and appears to affect carbohydrate and lipid metabolism via the action of insulin (Davis et al., 1997; Davis and Vincent, 1997). Increases in pre- and postpartum DMI have been reported with increasing chromium-L-methionine (Cr-Met) supplementation during the periparturient period (Hayirli et al., 2001; Smith et al., 2005). Several groups (Besong et al., 1996; Yang et al., 1996; Hayirli et al., 2001; Smith et al., 2005) have reported greater milk production as a result of $\mathrm{Cr}$ supplementation whereas others (Subiyatno et al., 1996; Pechova et al., 2002) have not observed this response.

Feeding diets containing higher NFC content has also been suggested for the transition period in order to stimulate ruminal papillae development, increase potential absorptive capacity of the rumen epithelium, and facilitate ruminal microbial adaptations to higher postpartum NFC levels. The fermentability of NFC in diets fed to prepartum and early postpartum dairy cows has also been investigated (Dann et al., 1999). One way 
to change ruminal carbohydrate fermentability is by substituting ground barley with ground corn. Eighty to $90 \%$ of barley starch and 55 to $70 \%$ of corn starch is digested in the rumen (Nocek and Tamminga, 1991), resulting in a greater proportion of corn starch reaching the small intestine relative to barley. Previous reports have demonstrated the energetic benefit of starch digestion in the small intestine compared with starch digestion and absorption of the resulting VFA in the rumen (Owens et al., 1986; Boss and Bowman, 1996), but evidence is still scant for an energetic or production benefit in lactating animals. There are ambiguous results concerning the relationship between corn- and barley-based diets (CBD and BBD, respectively) and DMI and milk yield in the literature (Mc Carthy et al., 1989; Grings et al., 1992; Khorasani et al., 1994; Casper et al., 1999).

Recently, Smith et al. (2005) investigated whether peripartal performance is affected by carbohydrate source and Cr supplementation. However, it is unknown whether productive performance and DMI are affected by $\mathrm{Cr}$ supplementation and substituting barley grain with corn throughout the transition period.

The current study was designed to investigate the effects of $\mathrm{Cr}$ supplementation and dietary grain source (barley vs. corn) on performance and lactation during the periparturient period.

\section{MATERIALS AND METHODS}

\section{Animals, Diets, and Treatments}

Thirty-two nonlactating, multiparous Holstein cows in late gestation were housed in individual tie-stalls from 4 wk before anticipated calving date through $4 \mathrm{wk}$ after parturition. Cows were assigned to 1 of 4 treatment groups in a $2 \times 2$ factorial arrangement of grain source and Cr level: BBD or CBD with or without $\mathrm{Cr}$ supplementation.

Cows were fed TMR (Table 1), according to NRC (2001) recommendations, once daily prepartum and twice daily postpartum ad libitum and had free access to water. Starting $21 \mathrm{~d}$ before calving, cows also received 0 or $0.08 \mathrm{mg}$ of $\mathrm{Cr} / \mathrm{kg}$ of $\mathrm{BW}^{0.75}$ as Cr-Met $[10 \%$ Cr and 90\% Met (wt/wt); MicroPlex 1000, Zinpro, Inc., Eden Prairie, MN] once daily, top dressed with $200 \mathrm{~g}$ of ground barley for the BBD or with the same amount of corn for the CBD; postpartum cows received 0 or $0.08 \mathrm{mg}$ of $\mathrm{Cr} / \mathrm{kg}$ of $\mathrm{BW}^{0.75}$ as Cr-Met, top dressed, in 2 equal allocations in the morning and afternoon feedings. The amount of Cr-Met offered to cows during the prepartum period was based on their BW as measured on d 22 before expected calving. Postpartum Cr-Met supplementation was adjusted based on a cow's BW on the day after calving. Because $\mathrm{Cr}$ requirements of dairy cows are not known (NRC, 2001), the dosage of Cr used in this study was chosen based on previous literature (Hayirli et al., 2001; Smith et al., 2005).

\section{Sample Collection and Analyses}

Amounts of TMR offered and orts were recorded daily for individual cows and daily DMI was determined. The DM contents of roughages and concentrates were determined on a weekly basis during the experiment in order to maintain the desired dietary forage:concentrate ratio. Monthly composite samples of forages and concentrates were prepared from the individual weekly samples. Feces were sampled for $5 \mathrm{~d}$ after 2 wk of feeding the experimental diets. The samples were dried at $55^{\circ} \mathrm{C}$ for $48 \mathrm{~h}$, ground using a Wiley mill (Wiley's pulverizer for laboratory, Ogaw Seiki Co., Ltd., Tokyo, Japan) to pass a $1-\mathrm{mm}$ screen, and stored at $-20^{\circ} \mathrm{C}$ until analysis. Monthly composite feed samples were analyzed for CP (method 988.05; AOAC, 1990), NDF (using heat-resistant $\alpha$-amylase without sodium sulfite; Van Soest et al., 1991), ADF (method 973.18; AOAC, 1990), ether extract (method 920.39; AOAC, 1990), ash (method 942.05; AOAC, 1990), and acid-insoluble ash (Van Keulen and Young, 1977; Table 1 and Table 2 ). Acid-insoluble ash was used as an internal marker to determine the coefficient of total-tract apparent digestibility. The DM, OM, CP, NDF, ADF, and acidinsoluble ash levels of the fecal samples were also determined. Blood samples were collected approximately 2.5 $\mathrm{h}$ after the morning feeding via the coccygeal vein using heparinized vacuum tubes (Becton Dickinson, Franklin Lakes, NJ) on d 22 before the expected calving date, immediately after parturition, and on d 21 postpartum. The blood metabolite and hormone data are not presented herein.

After parturition, cows were milked 3 times daily in the milking parlor and yields were recorded at each milking. Milk samples were collected weekly from 3 consecutive milkings (i.e., cows were milked 3 times daily and produced 3 samples/d per week) and preserved using potassium dichromate. Milk samples were analyzed for fat, protein, lactose, and total solid by an automated near-infrared spectroscopy analyzer (MilkoScan, 134 BN, Foss Electric, Hillerød, Denmark).

Body weights were measured on d 22 before expected calving date and on d 1, 7, 21, and 28 postpartum. Postpartum net energy balance (NEB) for each cow was calculated, based on NRC (2001), with the following formula: $\mathrm{NEB}=\left(\mathrm{DMI} \times \mathrm{NE}_{\mathrm{L}}\right.$ diet $)-[(0.08 \times$ $\left.\mathrm{BW}^{0.75}\right)+(0.0929 \times$ fat $+0.0563 \times$ protein +0.0395 $\times$ lactose $) \times$ milk yield $)]$. 
Table 1. Ingredient and nutrient composition (DM basis) of prepartum and postpartum diets, including a barley-based diet (BBD) and a corn-based diet (CBD)

\begin{tabular}{|c|c|c|c|c|}
\hline \multirow[b]{2}{*}{ Item } & \multicolumn{2}{|c|}{ Prepartum diet } & \multicolumn{2}{|c|}{ Postpartum diet } \\
\hline & $\mathrm{BBD}$ & $\mathrm{CBD}$ & $\mathrm{BBD}$ & $\mathrm{CBD}$ \\
\hline \multicolumn{5}{|l|}{ Ingredient, \% } \\
\hline Alfalfa hay & 22.0 & 22.0 & 24.8 & 24.8 \\
\hline Corn silage & 28.6 & 28.6 & 18.9 & 18.9 \\
\hline Wheat straw & 7.2 & 7.2 & - & - \\
\hline Coarse ground barley & 20.6 & - & 27.8 & - \\
\hline Coarse ground corn & - & 20.6 & - & 27.8 \\
\hline Whole linted cottonseed & 1.9 & 1.9 & 3.0 & 3.0 \\
\hline Cottonseed meal & 6.1 & 6.1 & 4.9 & 4.9 \\
\hline Soybean meal & 8.0 & 8.0 & 14.9 & 14.9 \\
\hline Fat supplement & - & - & 2.2 & 2.2 \\
\hline Calcium carbonate & 1.4 & 1.4 & 1.0 & 1.0 \\
\hline Sodium bicarbonate & - & - & 1.0 & 1.0 \\
\hline Vitamin and mineral mix $1^{1}$ & 4.2 & 4.2 & - & 1.0 \\
\hline Vitamin and mineral mix $2^{2}$ & - & - & 1.5 & 1.5 \\
\hline \multicolumn{5}{|l|}{ Chemical composition } \\
\hline $\mathrm{NE}_{\mathrm{L}},{ }^{3} \mathrm{Mcal} / \mathrm{kg}$ & 1.49 & 1.52 & 1.67 & 1.70 \\
\hline $\mathrm{DM}$ & 45.5 & 44.9 & 58.7 & 59.4 \\
\hline $\mathrm{OM}$ & 89.0 & 89.2 & 91.3 & 91.0 \\
\hline $\mathrm{CP}$ & 14.9 & 14.3 & 16.9 & 16.5 \\
\hline $\mathrm{NDF}$ & 41.9 & 39.0 & 34.2 & 32.1 \\
\hline $\mathrm{ADF}$ & 26.2 & 25.1 & 21.9 & 21.0 \\
\hline $\mathrm{NFC}^{4}$ & 36.4 & 38.7 & 38.0 & 40.6 \\
\hline Ether extract & 2.30 & 2.49 & 4.50 & 5.10 \\
\hline $\mathrm{Ca}^{3}$ & 1.60 & 1.59 & 1.27 & 1.26 \\
\hline $\mathrm{P}^{3}$ & 0.40 & 0.39 & 0.38 & 0.37 \\
\hline
\end{tabular}

${ }^{1}$ Contained (DM basis): $15.2 \% \mathrm{Ca}, 2.44 \% \mathrm{Mg}, 10.46 \% \mathrm{Cl}, 0.04 \% \mathrm{~K}, 0.82 \% \mathrm{Na}, 3.5 \% \mathrm{~S}, 1,400 \mathrm{mg} / \mathrm{kg}$ Fe, 288.2 $\mathrm{mg} / \mathrm{kg}$ of Mn, $302.5 \mathrm{mg} / \mathrm{kg}$ of Cu, $12.7 \mathrm{mg} / \mathrm{kg}$ of I, $504 \mathrm{mg} / \mathrm{kg}$ of Zn, $150 \mathrm{kIU} / \mathrm{kg}$ of vitamin A, $50 \mathrm{kIU} / \mathrm{kg}$ of vitamin $\mathrm{D}_{3}, 2,000 \mathrm{IU} / \mathrm{kg}$ of vitamin $\mathrm{E}$.

${ }^{2}$ Contained: $12 \% \mathrm{Ca}, 2 \% \mathrm{P}, 2.05 \% \mathrm{Mg}, 18.6 \% \mathrm{Na}, 0.3 \% \mathrm{~S}, 1,250 \mathrm{mg} / \mathrm{kg}$ of Fe, $2,250 \mathrm{mg} / \mathrm{kg}$ of Mn, 7,700 mg $/ \mathrm{kg}$ of $\mathrm{Zn}, 14 \mathrm{mg} / \mathrm{kg}$ of Co, $1,250 \mathrm{mg} / \mathrm{kg}$ of Cu, $56 \mathrm{mg} / \mathrm{kg}$ of I, $10 \mathrm{mg} / \mathrm{kg}$ of Se, $250 \mathrm{kIU} / \mathrm{kg}$ of vitamin A, $50 \mathrm{kIU} /$ $\mathrm{kg}$ of vitamin $\mathrm{D}_{3}, 1.5 \mathrm{kIU} / \mathrm{kg}$ of vitamin $\mathrm{E}$.

${ }^{3}$ Calculated according to NRC (2001).

${ }^{4} \mathrm{NFC}$ calculated as $100-(\% \mathrm{NDF}+\% \mathrm{CP}+\%$ ether extract $+\%$ ash $)(\mathrm{NRC}, 2001)$.

\section{Statistical Analyses}

Cows were blocked according to expected calving dates and then were assigned randomly to 1 of 4 treatments. The first week of the experiment was an adaptation period. The adaptation period values for DMI and BW were used as covariates for analysis of covariance applied to their corresponding measurements during the experimental period. Daily DMI and milk yield values were used during statistical analysis. However, they were reduced to weekly means in order to calculate en- ergy balance and yields of milk components. Analysis of covariance was conducted using the MIXED procedure of SAS Institute (1999), using repeated measures with first-order autoregressive covariance structure in time. The model included the effects of Cr-Met supplementation, grain source, interaction of Cr-Met and grain source, day, and 2- and 3-way interactions of main effects with day. Results are presented as least squares means and standard error of the mean. A threshold of significance was set at $P \leq 0.05$; trends were declared at $0.05<P<0.15$.

Table 2. Chemical composition (\% of DM) of the forages

\begin{tabular}{lccccc}
\hline & \multicolumn{3}{c}{ Alfalfa } & & \multicolumn{2}{c}{ Corn silage } \\
\cline { 2 - 3 } \cline { 5 - 6 } Item & Mean & SEM & & Mean & SEM \\
\hline DM, \% & 91.8 & 0.53 & & 23.4 & 0.64 \\
OM & 89.5 & 0.74 & & 8.2 & 0.22 \\
CP & 15.6 & 1.51 & & 54.5 & 0.45 \\
NDF & 51.9 & 1.17 & & 34.4 & 1.66 \\
ADF & 39.9 & & &
\end{tabular}




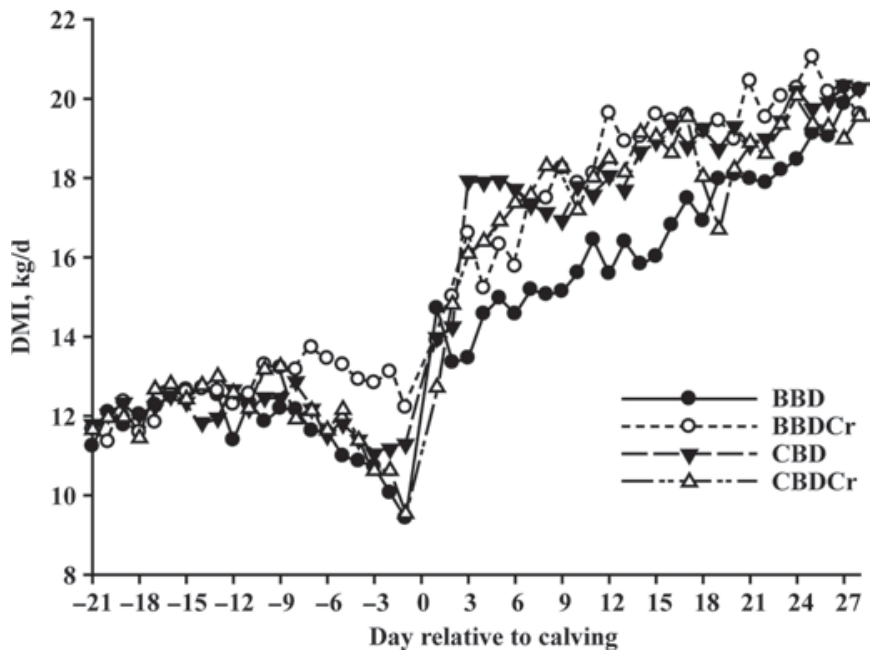

Figure 1. Daily prepartum and postpartum DMI for cows fed a barley-based diet (BBD), a corn-based diet (CBD), a barley-based diet supplemented with Cr-Met (BBDCr), and a corn-based diet supplemented with $\mathrm{Cr}-\mathrm{Met}(\mathrm{CBDCr})$. Values are least squares means. During the prepartum period, the $P$-value for 3 -way interactions between treatments and day was 0.64 and pooled SEM was 0.35. During the postpartum period, the $P$-value for 3 -way interactions between treatments and day was 0.36 and pooled SEM was 0.59 .

\section{RESULTS}

\section{Chromium Effect}

During the prepartum period, DMI expressed as kilogram per day was not affected by Cr-Met supplementation (Table 3; Figure 1); however, there was a trend for increased daily DMI, expressed as a percentage of BW $(P=0.09)$, in cows fed the Cr-Met supplemented diets
(Table 3). The change in DMI as a percentage of BW from $19 \mathrm{~d}$ until $1 \mathrm{~d}$ before parturition was not affected by Cr-Met supplementation (Table 3). No differences resulting from Cr-Met supplementation were observed in postpartum DMI when expressed either as kilogram per day and percentage of BW (Table 3; Figure 1). Body weights and postpartum calculated NEB were not affected by Cr-Met supplementation (Table 3). There was a trend $(P=0.10)$ for the percentage change in BW to decrease with Cr-Met supplementation during the postpartum period.

Table 4 shows the effects of Cr-Met supplementation on milk yield and milk composition. A tendency $(P=$ 0.08 ; Figure 2) was observed for increased milk yield in cows fed Cr-Met-supplemented diets. Milk protein concentration decreased $(P<0.05)$ with Cr-Met supplementation; however, no significant effect on other milk constituents was observed. No changes in total-tract apparent digestibility of $\mathrm{DM}, \mathrm{OM}, \mathrm{CP}, \mathrm{NDF}$, and $\mathrm{ADF}$ with Cr-Met supplementation were observed during the trial.

\section{Grain Effect}

Prepartum and postpartum DMI expressed as kilogram per day and as a percentage of BW (Table 3; Figure 1) and the change in DMI as a percentage of BW from d 19 until d 1 before parturition were not affected by source of grain (Table 3). After parturition, BW, the percentage change in BW, postpartum calculated NEB (Table 3), and milk yield and composition (Table 4; Figure 2) were not affected by source of dietary grain.

Table 3. Effects of Cr supplementation and substituting barley grain with corn during the periparturient period on DMI, BW, and net energy balance (NEB) in dairy cows

\begin{tabular}{|c|c|c|c|c|c|c|c|c|}
\hline \multirow[b]{2}{*}{ Item } & \multicolumn{4}{|c|}{ Treatment $^{1}$} & \multirow[b]{2}{*}{ SEM } & \multicolumn{3}{|c|}{$P$-value ${ }^{2}$} \\
\hline & $\mathrm{BBD}$ & CBD & $\mathrm{BBD}$ & CBD & & $\mathrm{Cr}$ & G & $\mathrm{Cr} \times \mathrm{G}$ \\
\hline \multicolumn{9}{|l|}{ Prepartum } \\
\hline DMI, $\mathrm{kg} / \mathrm{d}$ & 11.6 & 12.1 & 12.7 & 11.9 & 0.35 & 0.17 & 0.67 & 0.05 \\
\hline DMI, $\%$ of BW & 1.62 & 1.67 & 1.80 & 1.70 & 0.06 & 0.09 & 0.70 & 0.22 \\
\hline DMI, $\mathrm{kg} / \mathrm{d}$ & 16.9 & 18.3 & 18.4 & 17.8 & 0.59 & 0.37 & 0.53 & 0.10 \\
\hline DMI, $\%$ of BW & 2.59 & 2.92 & 2.82 & 2.78 & 0.15 & 0.74 & 0.33 & 0.22 \\
\hline $\mathrm{BW}, \mathrm{kg}$ & 664.4 & 664.6 & 665.6 & 652.7 & 7.21 & 0.47 & 0.36 & 0.36 \\
\hline BW change, ${ }^{4} \%$ & -9.60 & -10.9 & -7.60 & -6.10 & 1.92 & 0.10 & 0.96 & 0.48 \\
\hline $\mathrm{NEB},{ }^{5}$ Mcal $/ \mathrm{d}$ & -8.20 & -6.60 & -8.40 & -7.70 & 1.62 & 0.69 & 0.47 & 0.79 \\
\hline
\end{tabular}

${ }^{1}$ Treatments: $\mathrm{Cr}(-)=$ without supplemental $\mathrm{Cr}$; $\mathrm{Cr}(+)=$ with supplemental $\mathrm{Cr}$; BBD = barley-based diet; CBD = corn-based diet.

${ }^{2}$ Statistical comparisons: $\mathrm{Cr}$ effects $=\mathrm{Cr}(+)$ vs. $\mathrm{Cr}(-)$; G effects $=\mathrm{BBD}$ vs. CBD; $\mathrm{Cr} \times \mathrm{G}$ effects $=\mathrm{Cr}$ by $\mathrm{G}$ interaction.

${ }^{3}$ Change in DMI expressed as percentage of BW from d 19 through d 1 before parturition.

${ }^{4} \mathrm{BW}$ change was from $\mathrm{d} 1$ to $\mathrm{d} 30$ postpartum.

${ }^{5} \mathrm{NEB}$ calculated based on NRC $(2001)$. Postpartum NEB $=\left(\mathrm{DMI} \times \mathrm{NE}_{\mathrm{L}}\right.$ diet $)-\left[\left(0.08 \times \mathrm{BW}^{0.75}\right)+(0.0929 \times\right.$ fat $+0.0563 \times$ protein + $0.0395 \times$ lactose $) \times$ milk yield) $]$. 


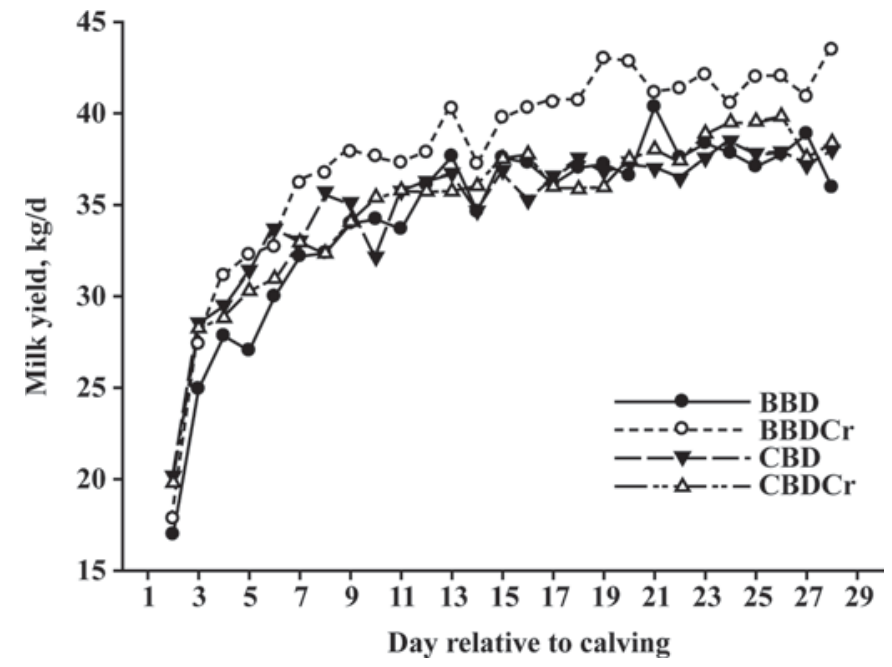

Figure 2. Milk yield during the postpartum period for cows fed a barley-based diet (BBD), a corn-based diet (CBD), a barley-based diet supplemented with Cr-Met (BBDCr), and a corn-based diet supplemented with Cr-Met (CBDCr). Values are least squares means; the $P$-value for 3 -way interactions between treatments and day was 0.88 and pooled SEM was 1.04 .

Total-tract apparent digestibility of the measured nutrients was higher for prepartum cows fed the CBD compared with those fed the BBD $(P<0.05$; Table 5).Total-tract apparent DM, OM, and CP digestibilities were higher $(P<0.05)$ for postpartum cows fed the BBD compared with those fed the CBD. There was also a trend for increased postpartum NDF and ADF digestibilities $(P=0.09$ and $P=0.08$, respectively $)$ in the BBD (Table 5).

\section{Chromium by Grain Interaction}

An interaction of $\mathrm{Cr}$ and grain was observed for prepartum DMI as $\mathrm{kg} / \mathrm{d}(P=0.05)$. The DMI increased when Cr-Met was added to the BBD but remained unchanged when Cr-Met was added to the CBD (Table 3). A trend was observed for an interaction between $\mathrm{Cr}$ and grain for the change in DMI as a percentage of $\mathrm{BW}$ from $19 \mathrm{~d}$ before parturition until $1 \mathrm{~d}$ before parturition $(P=0.12)$. The change in DMI was smaller when $\mathrm{Cr}-$ Met was added to the BBD but remained unchanged when Cr-Met was added to the CBD (Table 3). There was a trend for an interaction between $\mathrm{Cr}$ and grain for postpartum DMI as kilograms per day $(P=0.10)$. The DMI increased when the BBD was supplemented with Cr-Met but remained unchanged when the CBD supplemented with Cr-Met was fed (Table 3). No Cr by grain interaction was observed in DMI as a percentage of BW over the course of the experiment. No Cr by grain interactions were observed in $\mathrm{BW}$, the percentage change in BW, and postpartum calculated NEB during the postpartum period (Table 3). No $\mathrm{Cr}$ by grain interactions (Table 4) were observed for milk yield and composition except for milk $\mathrm{CP}(P=0.09)$ and total solid yields $(P=0.10)$. Yields of $\mathrm{CP}$ and total solids in milk increased when the BBD was supplemented with Cr-Met but remained unchanged when the CBD was supplemented with Cr-Met (Table 4). There were no 3-way interactions between treatments and day on pre- and postpartum DMI, BW, NEB, milk yield, and milk composition. A trend $(P=0.14)$ for 3 -way interactions was observed only for the percentage of milk total solids.

During the prepartum period, there were trends for the interactions between $\mathrm{Cr}$ and grain for total-tract apparent DM and OM digestibilities $(P<0.15)$. Totaltract apparent digestibility of $\mathrm{DM}$ and $\mathrm{OM}$ increased when Cr-Met was added to the BBD but were unchanged when Cr-Met was added to the CBD (Table $5)$.

Table 4. Effects of $\mathrm{Cr}$ supplementation and substituting barley grain with corn during the periparturient period on milk yield and milk composition in dairy cows

\begin{tabular}{|c|c|c|c|c|c|c|c|c|}
\hline Item & \multicolumn{4}{|c|}{ Treatment $^{1}$} & SEM & \multicolumn{3}{|c|}{$P$-value ${ }^{2}$} \\
\hline Milk, $\mathrm{kg} / \mathrm{d}$ & 34.3 & 34.9 & 37.7 & 35.2 & 1.04 & 0.08 & 0.37 & 0.16 \\
\hline $4 \% \mathrm{FCM}, \mathrm{kg} / \mathrm{d}$ & 36.1 & 38.2 & 40.5 & 38.2 & 1.56 & 0.17 & 0.98 & 0.17 \\
\hline Fat, $\%$ & 4.50 & 4.73 & 4.66 & 4.73 & 0.35 & 0.83 & 0.66 & 0.82 \\
\hline $\mathrm{CP}, \mathrm{kg} / \mathrm{d}$ & 1.01 & 1.11 & 1.10 & 1.03 & 0.05 & 0.90 & 0.78 & 0.09 \\
\hline Lactose, \% & 4.94 & 4.89 & 4.95 & 4.74 & 0.11 & 0.54 & 0.25 & 0.49 \\
\hline Lactose, $\mathrm{kg} / \mathrm{d}$ & 1.66 & 1.71 & 1.84 & 1.67 & 0.08 & 0.43 & 0.44 & 0.21 \\
\hline Total solid, \% & 12.8 & 13.1 & 12.8 & 12.7 & 0.36 & 0.67 & 0.84 & 0.60 \\
\hline Total solid, kg/d & 4.28 & 4.53 & 4.73 & 4.40 & 0.17 & 0.34 & 0.80 & 0.10 \\
\hline
\end{tabular}

${ }^{1}$ Treatments: $\mathrm{Cr}(-)=$ without supplemental $\mathrm{Cr}$; $\mathrm{Cr}(+)=$ with supplemental $\mathrm{Cr}$; BBD $=$ barley-based diet; CBD $=$ corn-based diet.

${ }^{2}$ Statistical comparisons: $\mathrm{Cr}$ effects $=\mathrm{Cr}(+)$ vs. $\mathrm{Cr}(-)$; G effects $=\mathrm{BBD}$ vs. CBD; $\mathrm{Cr} \times \mathrm{G}$ effects $=\mathrm{Cr}$ by $\mathrm{G}$ interaction. 
Table 5. Effects of Cr supplementation and substituting barley grain with corn during the periparturient period on total-tract digestibility of nutrients in dairy cows

\begin{tabular}{|c|c|c|c|c|c|c|c|c|}
\hline Digestibility, \% & \multicolumn{4}{|c|}{ Treatment $^{1}$} & SEM & \multicolumn{3}{|c|}{$P$-value ${ }^{2}$} \\
\hline \multicolumn{9}{|l|}{ Prepartum } \\
\hline DM & 58.0 & 65.0 & 60.4 & 64.6 & 0.84 & 0.26 & $<0.01$ & 0.12 \\
\hline $\mathrm{OM}$ & 60.6 & 67.1 & 63.1 & 66.9 & 0.87 & 0.20 & $<0.01$ & 0.13 \\
\hline $\mathrm{ADF}$ & 45.1 & 53.1 & 46.0 & 52.4 & 1.77 & 0.97 & $<0.01$ & 0.65 \\
\hline \multicolumn{9}{|l|}{ Postpartum } \\
\hline DM & 70.7 & 68.6 & 72.2 & 68.9 & 0.87 & 0.32 & $<0.01$ & 0.52 \\
\hline $\mathrm{OM}$ & 72.0 & 69.5 & 73.1 & 70.1 & 0.86 & 0.34 & $<0.01$ & 0.79 \\
\hline $\mathrm{CP}$ & 73.0 & 69.4 & 74.1 & 70.4 & 0.90 & 0.26 & $<0.01$ & 0.99 \\
\hline $\mathrm{NDF}$ & 57.6 & 54.8 & 59.2 & 56.1 & 1.55 & 0.35 & 0.09 & 0.94 \\
\hline $\mathrm{ADF}$ & 54.5 & 51.3 & 56.8 & 52.3 & 1.99 & 0.40 & 0.08 & 0.75 \\
\hline
\end{tabular}

${ }^{1}$ Treatments: $\mathrm{Cr}(-)=$ without supplemental $\mathrm{Cr}$; $\mathrm{Cr}(+)=$ with supplemental Cr; BBD = barley-based diet; CBD = corn-based diet.

${ }^{2}$ Statistical comparisons: $\mathrm{Cr}$ effects $=\mathrm{Cr}(+)$ vs. $\mathrm{Cr}(-)$; G effects $=\mathrm{BBD}$ vs. CBD; $\mathrm{Cr} \times \mathrm{G}$ effects $=\mathrm{Cr}$ by $\mathrm{G}$ interaction.

\section{DISCUSSION}

The chemical composition of prepartum and postpartum diets is presented in Table 1. The NFC content in the diet increased and NDF content decreased slightly as corn grain was substituted for barley as a result of the relatively high NFC and low NDF contents of corn compared with that of barley. It seems that the observed responses in this experiment were partially affected by differences in NDF and NFC concentrations in the BBD and CBD.

Studies regarding Cr supplementation in dairy cow nutrition have yielded contrasting results. Yang et al. (1996) reported increased DMI in response to $\mathrm{Cr}$ supplementation in primiparous cows during early lactation. Subsequently, Hayirli et al. (2001) reported that increasing Cr-Met supplementation during the periparturient period caused linear and quadratic increases in the pre- and postpartum DMI, respectively. These findings along with the unknown mechanisms of $\mathrm{Cr}$ action stimulated nutritionists to do further research in this field. Hayirli et al. (2001) suggested that the linear increase in DMI as a result of the increased Cr-Met intake during the periparturient period may be explained by an outweighing of a potential $\mathrm{Cr}$ deficiency. Conversely, Smith et al. (2005) reported a linear increase in DMI resulting from increased Cr-Met supplementation only during the postpartum period but not during the prepartum period. Therefore, additional research is required to determine whether the favorable responses to $\mathrm{Cr}$ supplementation in some experiments were a result of compensation for a potential $\mathrm{Cr}$ deficiency or of other factors related to the physiological mode of action of Cr. Chromium, as a part of chromodulin, is part of an insulin-potentiating pathway that can affect carbohydrate and lipid metabolism via the action of insulin (Davis et al., 1997; Davis and Vincent, 1997). The contrasting results are likely a result of differences in the Cr status of the animals, degree of stress, the amount and bioavailability of $\mathrm{Cr}$ in the basal diet, and in the supplemental Cr source (Kegley et al., 2000).

Grummer et al. (2004) suggested that the most important signal for initiating adipose tissue lipolysis may be the magnitude of intake depression rather than the level of DMI during the prepartum period. In the present study, Cr-Met supplementation did not affect the change in DMI, expressed as a percentage of BW, from d 19 through d 1 before parturition, which confirmed results reported by Smith et al. (2005) indicating that Cr-Met supplementation was not effective on the decline pattern of prepartum DMI.

In the present experiment, there was no effect of CrMet supplementation on BW; this is similar to the results reported by Hayirli et al. (2001), who showed that BW was not affected by increasing Cr-Met supplementation during the postpartum period. In contrast, Smith et al. (2005) reported that administering increasing amounts of Cr-Met linearly increased postpartum BW. There was no effect of Cr-Met supplementation on calculated NEB during the postpartum period, which agrees with the results reported by Smith et al. (2005). The lack of significant effect of Cr-Met supplementation on BW and calculated NEB may confirm the earlier conclusion stating that effects of Cr-Met administration on actual energy balance are minimal (Smith et al., 2005).

In the present experiment, the tendency for higher milk production by cows supplemented with $\mathrm{Cr}$ is in agreement with previously reported results (Besong et al., 1996; Yang et al., 1996; Hayirli et al., 2001; Smith 
et al., 2005). Others (Subiyatno et al., 1996; Pechova et al., 2002) have not observed this response on milk production.

The source of carbohydrate, its degradability in the rumen, and its availability in the lower digestive tract are crucial factors in ruminant energy intake. Allen (2000) compiled results from 10 experiments in which the site of starch digestion varied; differences in ruminally degraded starch as a percentage of total starch had no effect on DMI in 7 out of 10 comparisons, and the response was not associated with the ruminal starch degradability of the diet. The feeding frequency, the forage source, the starch source and its processing, and the availability of $\mathrm{N}$ substrates for microbial growth have been suggested as factors affecting the extent to which the site of starch digestion influences DM intake in lactating dairy cows (Reynolds et al., 1997). In the present experiment, only the source of dietary starch was different between diets; however, prepartum and postpartum DMI were not affected by this substitution.

In the present study, milk production was not affected by the source of grain in the diets. This result is in agreement with previous experiments conducted with dairy cows (Grings et al., 1992; Khorasani et al., 1994), and is in contrast with McCarthy et al. (1989) and Casper et al. (1999), who reported greater milk production by cows fed corn-based diets than by those fed barley-based diets. In a review of published studies, Nocek and Tamminga (1991) concluded that milk yield and milk composition were not influenced by the site of starch digestion; however, increased milk protein yield as a result of increased microbial protein synthesis with greater starch fermentation in the rumen has been reported (Theurer et al., 1999). The same milk protein content among treatments suggests that substituting ground barley with ground corn had little effect on rumen microbial protein synthesis and intestinal AA availability, and that AA delivery to the mammary gland was not different among treatments. Another factor, milk fat content, was unaffected by substituting ground barley with ground corn, as has been reported in other studies (Grings et al., 1992; Khorasani et al., 1994, 2001; Casper et al., 1999). However, higher milk fat percentage has been observed by others (DePeters and Taylor, 1985; Weiss et al., 1989) who fed cornbased diets instead of barley-based diets to the cows. These differential effects can probably be explained by differences in the inclusion rate of barley or corn in the diet, as marked effects were observed at higher portions of grain (Khorasani et al., 2001).

During the prepartum period, total-tract apparent digestibility of measured nutrients was lower for cows fed the BBD compared with cows fed the CBD. A more pronounced effect on rumen ecology from rapidly degradable starch sources such as barley, compared with less degradable starch sources such as corn, has already been reported (Ørskov, 1976). However, the BBD had more NDF and less NFC than the CBD, which may have contributed to the lower digestibility of the $\mathrm{BBD}$ in the prepartum period. Conversely, the BBD had higher nutrient digestibility compared with the CBD during the postpartum period. Reasons for the increase in nutrient digestibility of the BBD in the postpartum period are unknown. It seems, however, that the lower proportion of forage in the postpartum period compared with that in the prepartum period may have played a role and concealed the differences in NDF content between the diets. Less of the NDF was from forage in the postpartum period, whereas much more of the NDF was from forage in the prepartum period and therefore may have had a greater effect on nutrient digestibility. Khorasani et al. (2001) found a minimal effect of substituting barley with corn on digestibility of DM, $\mathrm{OM}$, and NDF, except in the case of $\mathrm{CP}$, which was less for cows fed a corn-based diet than for those fed a barley-based diet. McCarthy et al. (1989) reported that total-tract digestibility of NDF was higher for cows fed a corn-based diet than those fed a barley-based diet, even though total-tract digestibility of ADF was not different between sources of grains. A recent report from Reynolds (2006) indicated that in the studies in which barley grain is substituted for corn grain, the forage source in the diets plays a critical role in the negative effect of rapidly degradable barley starch on fiber digestion. This might explain some discrepancies among experiments and confirm conflict between the forage and carbohydrate source in rumen fermentation and the bypass of the forage and carbohydrate source.

An interesting finding of the present study was the increased DMI in periparturient cows fed the BBD supplemented with Cr-Met. The mechanisms by which Cr-Met increased feed intake remain unclear. However, it is known that $\mathrm{Cr}$ is part of an insulin-potentiating pathway and there is limited evidence that insulin has a stimulatory effect on ruminal papillae development (Sakata et al., 1980). Greater ruminal papillae development can improve VFA absorption and stabilize the ruminal environment (Allen, 1997), hence a greater DMI can be observed particularly when a rapidly fermentable starch source is fed. Therefore, we infer that higher feed intake in cows fed the BBD supplemented with Cr-Met may be the result of a greater VFA absorption capacity. That no change in DMI of the CBD after Cr-Met supplementation was observed suggests that Cr-Met was more effective in diets based on rapidly degradable starch sources (barley) than diets based on slowly degradable starch sources (corn). 


\section{CONCLUSIONS}

Supplementation with Cr-Met during the periparturient period can increase milk yield whereas milk protein content decreases. Our data indicate that neither DMI nor productive performance are affected by substituting barley grain with corn. Finally, the data indicate that the beneficial effect of Cr-Met supplementation during the periparturient period in order to improve feed intake may depend on the grain source of the diet, which was shown in improvement of pre- and postpartum DMI in cows fed the BBD supplemented with Cr-Met.

\section{ACKNOWLEDGMENTS}

The authors express their appreciation to Isfahan University of Technology (IUT, Isfahan, Iran) for financial support of this study; to the staff at Lavark Research Station (IUT) for diligent animal care; to Farzad Hashemzadeh and Behrouz Ghods Alavi (IUT) for their help in conducting this experiment; to Sana Dam Pars Company for partial financial support of this experiment; and to Armagan Hayirli (Atatürk University, Erzurum, Turkey) for his helpful review of the manuscript.

\section{REFERENCES}

Allen, M. S. 1997. Relationship between fermentation acid production in the rumen and the requirement for physical effective fiber. J. Dairy Sci. 80:1447-1462.

Allen, M. S. 2000. Effects of diet on short term regulation of feed intake by dairy cattle. J. Dairy Sci. 83:1598-1624.

Association of Official Analytical Chemists. 1990. Official Methods of Analysis. 15th ed. AOAC, Arlington, VA.

Besong, S., J. A. Jackson, D. S. Trammel, and V. Akay. 1996 Influence of supplemental chromium on concentrations of liver triglyceride, blood metabolites, and rumen VFA profiles in steers fed a moderately high fat diet. J. Dairy Sci. 84:1679-1685.

Boss, D. L., and J. G. P. Bowman. 1996. Barley varieties for finishing steers: II. Ruminal characteristics and rate, site, and extent of digestion. J. Anim. Sci. 74:1973-1981.

Casper, D. P., H. A. Maiga, M. J. Brouk, and D. J. Schingoethe 1999. Synchronization of carbohydrate and protein sources on fermentation and passage rate in dairy cows. J. Dairy Sci. 82:1779-1790.

Dann, H. M., G. A. Varga, and D. E. Putnam. 1999. Improving energy supply to late gestation and early postpartum dairy cows. J. Dairy Sci. $82: 1765-1778$

Davis, C. M., A. C. Royer, and J. B. Vinsent. 1997. Synthetic multinuclear chromium assembly activates insulin receptor kinase activity: Functional model for low-molecular-weight chromiumbinding substance. Inorg. Chem. 36:5316-5320.

Davis, C. M., and J. B. Vincent. 1997. Chromium oligopeptide activates insulin receptor tyrosine kinase activity. Biochemistry 36:4382-4385.

DePeters, E. J., and S. J. Taylor. 1985. Effects of feeding corn or barley on composition of milk and diet digestibility. J. Dairy Sci. 68:2027-2032

Grings, E. E., R. E. Roffler, and D. P. Deitelhoff. 1992. Evaluation of corn and barley as energy sources for cows in early lactation fed alfalfa-based diets. J. Dairy Sci. 75:193-200.

Grummer, R. R. 1995. Impact of changes in organic nutrient metabolism on feeding the transition dairy cows. J. Anim. Sci. 73:2820-2833.

Grummer, R. R., G. D. Mashek, and A. Hayirli. 2004. Dry matter intake and energy balance in the transition period. Vet. Clin. Food. Anim. 20:447-470.
Hayirli, A., D. R. Bremmer, S. J. Bertics, M. T. Socha, and R. R. Grummer. 2001. Effect of chromium supplementation on production and metabolic parameters in periparturient dairy cows. J. Dairy Sci. 84:1218-1230.

Hayirli, A., R. R. Grummer, E. V. Nordheim, and P. M. Crump. 2002. Animal and dietary factors affecting feed intake during the prefresh transition period in Holsteins. J. Dairy Sci. 85:3430-3443.

Kegley, E. B., D. L. Galloway, and T. M. Fakler. 2000. Effect of dietary chromium-L-methionine on glucose metabolism of beef steers. J. Anim. Sci. 78:3177-3183.

Khorasani, G. R.. G. de Boer, B. Robinson, and J. J. Kennelly. 1994. Influence of dietary protein and starch on production and metabolic responses of dairy cows. J. Dairy Sci. 77:813-824.

Khorasani, G. R., E. K. Okine, and J. J. Kennely. 2001. Effects of substituting barley grain with corn on ruminal fermentation characteristics, milk yield, and milk composition of Holstein cows. J. Dairy Sci. 84:2760-2769.

McCarthy, R. D. Jr., T. H. Klusmeyer, J. L. Vicini, J. H. Clark, and D. R. Nelson. 1989. Effects of source of protein and carbohydrate on ruminal fermentation and passage of nutrients to the small intestine of lactating cows. J. Dairy Sci. 72:2002-2016.

NRC. 2001. Nutrient Requirement of Dairy Cattle. 7th rev. ed. Natl. Acad. Sci., Washington, DC.

Nocek, J. E., and S. Tamminga. 1991. Site of digestion of starch in the gastrointestinal tract of dairy cows and its effect on milk yield and composition. J. Dairy Sci. 74:3598-3629.

Ørskov, E. R. 1976. The effect of processing on digestion and utilization of cereals by ruminants. Proc. Nutr. Soc. 35:245-252.

Owens, F. N., R. A. Zinn, and Y. K. Kim. 1986. Limits to starch digestion in the ruminant small intestine. J. Anim. Sci. 63:16341648.

Pechova, A., A. Podhorsky, E. Lokajova, L. Pavlata, and J. Illek. 2002. Metabolic effects of chromium supplementation in dairy cows in the peripartal period. Acta Vet. Brno 71:9-18.

Reynolds, C. K. 2006. Production and metabolic effects of site of starch digestion in dairy cattle. Anim. Feed Sci. Technol. 130:78-94.

Reynolds, C. K., J. D. Sutton, and D. E. Beever. 1997. Effects of feeding starch to dairy cows on nutrient availability and production. Page 105 in Recent Advances in Animal Nutrition, Proceedings of the 30th University of Nottingham Conference for Feed Manufacturers. P. C. Gransworthy and J. Wiseman, ed. University of Nottingham Press, Nottingham, UK

Sakata, T., Y. Hikosaka, Y. Shimura, and H. Tamate. 1980. Stimulatory effect of insulin on rumen epithelium cell mitosis in adult sheep. Br. J. Nutr. 44:325-331.

SAS Institute. 1999. SAS User's Guide: Statistics. Version 8.2 ed. SAS Institute Inc., Cary, NC

Smith, K. L., M. R. Waldron, J. K. Drackley, M. T. Socha, and T. R. Overton. 2005. Performance of dairy cows as affected by prepartum dietary carbohydrate source and supplementation with chromium throughout the transition period. J. Dairy Sci. 88:255-263.

Subiyatno, A., D. N. Mowat, and W. Z. Yang. 1996. Metabolite and hormonal response to glucose or propionate infusion in periparturient dairy cows supplemented with chromium. J. Dairy Sci. $79: 1436-1445$.

Theurer, C. B., J. T. Huber, A. Delgado-Elorduy, and R. Wanderley 1999. Invited review: Summary of steam-flaking corn or sorghum grain for lactating dairy cows. J. Dairy Sci. 82:1950-1959.

Van Keulen, V., and B. H. Young. 1977. Evaluation of acid-insoluble ash as natural marker in ruminant digestibility studies. J. Anim. Sci. 26:119-135.

Van Soest, P. J., J. B. Robertson, and B. A. Lewis. 1991. Methods for dietary fiber, neutral detergent fiber, and nonstarch polysaccharides in relation to animal nutrition. J. Dairy Sci. 74:3583-3597.

Weiss, W. P., G. R. Fisher, and G. M. Erickson. 1989. Effect of source of neutral detergent fiber and starch on nutrient utilization by dairy cows. J. Dairy Sci. 72:2308-2315.

Yang, W. Z., D. N. Mowat, A. Subiyatno, and R. M. Liptrap. 1996. Effects of chromium supplementation on early lactation performance of Holstein cows. Can. J. Anim. Sci. 76:221-230. 